Available online at: http://journal.unj.ac.id

Jurnal

Pensil

Pendidikan Teknik Sipil

Journal homepage: http://journal.unj.ac.id/unj/index.php/ipensil/index

\title{
METODE GRAFIS UNTUK PENGGAMBARAN DIAGRAM GESER DAN MOMEN PADA BALOK
}

\section{GRAPHICAL METHOD FOR CONSTRUCTING INTERNAL SHEAR AND BENDING MOMENT DIAGRAM ON BEAMS}

\author{
Andry Alim Lingga', Edwin Lim² \\ ${ }^{1}$ Universitas Tanjungpura, Jl. Prof. Dr. H. Hadari Nawawi, Bansir Laut, Kec. Pontianak \\ Tenggara, Kota Pontianak, Kalimantan Barat 78124, Indonesia \\ ${ }^{2}$ Tacoma Community College, 6501 S 19th St, Tacoma, WA 98466, Amerika Serikat \\ 1andryalim@,civil.untan.ac.id, ${ }^{2}$ elim@,tacomacc.edu
}
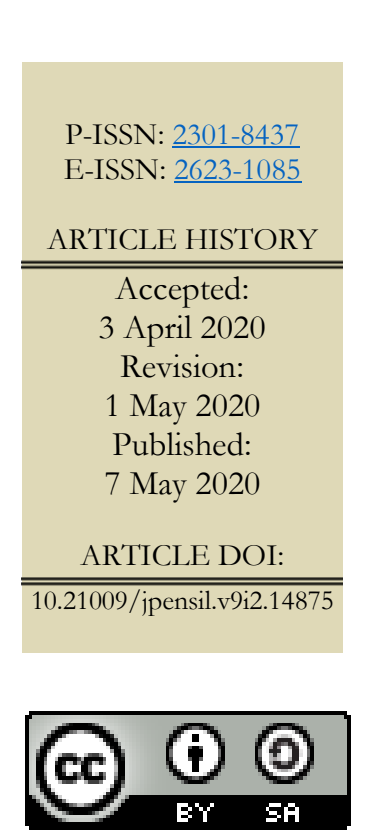

Jurnal Pensil :

Pendidikan Teknik

Sipil is licensed under a

Creative Commons

Attribution-ShareAlike

4.0 International License

(CC BY-SA 4.0).

\begin{abstract}
Abstrak
Metode perumusan persamaan bidang geser dan momen (metode persamaan) sering menjadi hambatan bagi mahasiswa dalam pemahaman materi bidang geser dan momen di mata kuliah Statika. Kesulitan ini dapat dihilangkan dengan memperkenalkan metode grafis dalam penggambaran bidang geser dan momen kepada mahasiswa sebagai metode alternatif atau pendukung. Untuk mempelajari pengaruh metode grafis dalam pemahaman mahasiswa akan materi ini, peneliti menggunakan satu kelas kontrol (metode persamaan) dan dua kelas eksperimen (metode grafis). Penelitian dilakukan terhadap mahasiswa yang mengambil mata kuliah Statika di Universitas Tanjungpura, Pontianak. Ujian akhir semester dijadikan instrumen untuk menilai tingkat pemahaman mahasiswa akan materi penggambaran bidang geser dan momen. Pengujian hipotesis dengan metode Mann-Whitney dilakukan untuk membantah null hipotesis $\left(\mathrm{H}_{0}\right)$ bahwa tidak ada perbedaan signifikan antara kelas eksperimen dan kelas kontrol. Hasil analisis uji hipotesis memberikan nilai $z_{\text {hitung }}<z_{\text {crit }}$ ( $z_{\text {hitung }}$ dan $z_{\text {crit }}$ mempunyai nilai negatif) untuk kedua kelas eksperimen, sehingga dapat disimpulkan bahwa terdapat perbedaan hasil belajar yang signifikan antara mahasiswa yang mendapatkan materi metode grafis dengan mahasiswa yang mendapatkan materi metode persamaan.
\end{abstract}

Kata kunci: balok, gaya - gaya dalam, metode grafis, statika

\footnotetext{
Abstract

Statics is a fundamental knowledge that should be mastered by many engineering students before learning more advanced engineering mechanics courses. General topics covered in this course include vector operations, equilibrium of particles, moment, compound structures, and internal forces. The later topic, internal forces, is usually difficult for students to comprehend, especially in terms of sketching proper internal shear and moment diagrams. In many universities in Indonesia, this topic is delivered
} 
using equation method in which students need to make freebody cuts before writing governing equations used to plot the shear and moment diagrams. This method is complex and thus susceptible to mistakes. This complexity could be reduced by using graphical method in sketching the shear and moment diagrams. This graphical method applies six rules derived based on relations of external load, shear diagram, and moment diagram. This graphical method is introduced to students taking the Statics I course at Tanjungpura University. Comparisons of the results of final exams from three different classes show that there is a positive significant difference on the results of final exams for students taught using graphical method.

Keywords: Beams, Graphical method, Internal forces, Statics

\section{Pendahuluan}

Statika merupakan ilmu yang mempelajari kesetimbangan gaya - gaya yang bekerja pada struktur termasuk gaya - gaya dalam yang dapat terjadi pada elemen struktur. Sebagai salah satu mata kuliah dasar di bidang mekanika teknik, banyak peneliti yang mempelajari metode pengajaran dan pembelajaran untuk mata kuliah ini (Hardiyanti et al., 2012, Utami et al., 2016) dengan tujuan meningkatkan pemahaman siswa ataupun mahasiswa akan topik ini.

Di Universitas Tanjungpura, mata kuliah Statika dibagi menjadi 2: Statika I: Struktur Statis Tertentu dan Statika II: Rangka Batang. Statika I menitik beratkan pada perhitungan reaksi perletakan, gaya gaya dalam balok, dan garis pengaruh. Statika II menekankan materi mengenai rangka batang (trusses). Pada mata kuliah Statika I dapat dikatakan topik mengenai gaya - gaya dalam pada balok merupakan materi yang paling sulit dipahami oleh mahasiswa. Hal ini kemungkinan besar disebabkan oleh konsep gaya - gaya dalam yang abstrak (non-fisikal) sehingga sulit untuk ditunjukkan seperti apa bentuk fisik dari gaya - gaya dalam ini. Selain itu, tantangan kalkulasi juga signifikan. Kesulitan kalkulasi ini tidak terlepas dari metode yang lazimnya diperkenalkan untuk menyelesaikan soal - soal berkaitan dengan topik ini (metode persamaan). Dalam metode ini, setelah mahasiswa membagi balok menjadi beberapa freebody berdasarkan perletakan dan gaya - gaya luar, persamaan persamaan harus diformulasikan berdasarkan prinsip kesetimbangan pada masing - masing freebody. Tahap ini sangat rentan akan kesalahan umum yang sering terjadi pada mata kuliah Statika yaitu penggambaran diagram freebody dan perumusan persamaan kesetimbangan (Steif \& Dantzler, 2005, pp. 363 - 371). Kesulitan bertambah disaat bidang - bidang gaya dalam harus digambarkan berdasarkan persamaan tersebut; apakah kurva bidang gaya dalamnya berupa garis lurus, melengkung ke luar atau ke atas, berapa nilai momen maksimum dan minimum.

Metode grafis (Goodno, 2019, pp.372419) merupakan metode alternatif yang dapat ditawarkan ke mahasiswa dalam mengkonstruksi bidang - bidang gaya dalam. Pada metode ini, setelah mahasiswa menghitung reaksi perletakan pada struktur balok, mereka dapat langsung mengaplikasikan enam aturan untuk penggambaran bidang gaya - gaya dalam. Enam aturan ini diturunkan melalui hubungan antara gaya - gaya luar dengan bidang geser dan momen.

Metode grafis ini diterapkan kepada mahasiswa yang mengambil mata kuliah Statika I di Universitas Tanjungpura, dan mendapatkan respons positif dari mahasiswa karena mudah diaplikasikan dan meningkatkan pemahaman pada topik ini. Pengujian hipotesis mengenai perbandingan penerapan metode grafis dan metode 
persamaan juga dilakukan berdasarkan hasil ujian akhir pada tiga kelas yang berbeda. Pengujian ini dilakukan untuk melihat apakah terjadi perbedaan hasil ujian yang signifikan antara metode grafis dan metode persamaan.

\section{Metode Persamaan}

Metode persamaan merupakan metode yang umumnya diperkenalkan dalam topik penggambaran bidang - bidang gaya dalam di sebagian besar universitas di Indonesia. Langkah - langkah yang harus diselesaikan mahasiswa untuk penerapan metode persamaan ini meliputi:

1. Perhitungan reaksi perletakan

2. Pembagian struktur menjadi freebody berdasarkan perletakan, gaya - gaya luar, dan konfigurasi struktur

3. Penyusunan persamaan gaya - gaya dalam berdasarkan prinsip hukum kesetimbangan pada masing - masing freebody yang sudah di gambar pada langkah sebelumnya

4. Penggambaran bidang - bidang gaya dalam berdasarkan persamaan yang sudah diturunkan pada langkah sebelumnya.

Metode ini sangat populer di banyak universitas di Indonesia karena perumusannya yang masih berhubungan dengan prinsip hukum kesetimbangan yang telah dipelajari mahasiswa pada topik sebelumnya, seperti topik perhitungan reaksi perletakan. Akan tetapi karena sifat abstrak dari gaya - gaya dalam, kompleksitas dari metode ini, dan tingkat pemahaman terhadap sifat - sifat persamaan (kelengkungan kurva, turunan), maka metode ini termasuk salah satu topik yang sulit dipahami oleh mahasiswa dan, kalaupun dapat dipahami, penerapannya sangat rentan terhadap kesalahan terutama akibat ketidaktelitian. Langkah - langkah penyelesaian dengan metode persamaan dapat dijelaskan lebih jauh melalui contoh soal dibawah ini.
Contoh Soal Penyelesaian dengan Metode Persamaan

Sebuah balok ditumpu dengan sendi di titik $A$ dan roller di titik $B$. Beban merata diaplikasikan pada balok tersebut dari titik $A$ ke $C$. Panjang total balok adalah $8 \mathrm{~m}$ (Lihat Gambar 1).

Penyelesaian - Langkah 1: Perbitungan Reaksi perletakan

Reaksi perletakan pada balok akibat beban merata $w_{o}=10 \mathrm{kN} / \mathrm{m}$ dapat dihitung dengan persamaan kesetimbangan $\left(\sum F_{y}=0\right.$, $\left.\sum F_{x}=0, \sum M=0\right)$. Dari perhitungan tersebut didapatkan reaksi perletakan pada sendi $A$ adalah $26.67 \mathrm{kN}$ (vertikal) dan pada roller $B$ adalah $53.33 \mathrm{kN}$ (vertikal).

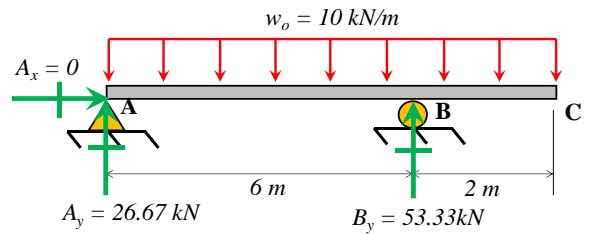

Gambar 1. Contoh Soal 1

Penyelesaian - Langkah 2: Pembagian struktur menjadi freebody berdasarkan perletakan, gaya gaya luar, dan konfigurasi struktur

Berdasarkan observasi terhadap lokasi perletakan, pembebanan dan konfigurasi struktur, maka balok ini dapat dibagi menjadi dua bentang untuk tujuan perumusan persamaan gaya - gaya dalam. Pada beberapa jenis soal dengan lokasi perletakan dan pembebanan yang lebih rumit, mahasiswa dapat mengalami kebingungan menentukan jumlah bentang yang dimaksud pada tahap ini.

Freebody diagram kiri (FBKi) dan kanan $(F B K a)$ pada potongan bentang pertama dan kedua struktur balok ditunjukkan pada Gambar 2 dan 3 di bawah ini. Pada diagram tersebut, Gaya dalam momen dan geser digambarkan pada arah positif sesuai dengan ketentuan yang berlaku pada umumnya. Selain itu, gaya dalam aksial tidak digambarkan karena besarannya yang nol. 


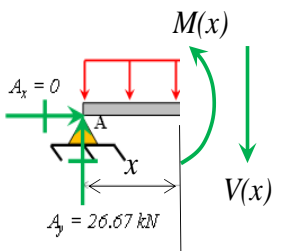

$\underline{F B K i}$

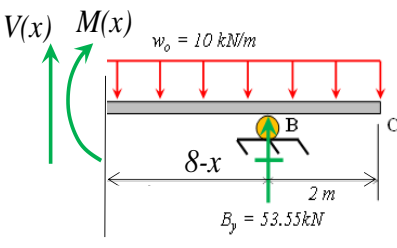

$\underline{F B K a}$
Gambar 2. Freebody kiri (FBKi) dan kanan $(\mathrm{FBKa})$ pada potongan bentang pertama

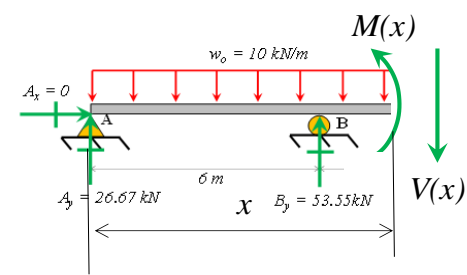

$\underline{F B K i}$

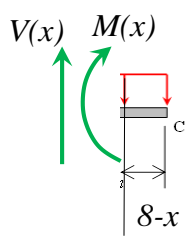

$\underline{F B K a}$
Gambar 3. Freebody kiri (FBKi) dan kanan $(\mathrm{FBKa})$ pada potongan bentang kedua

Pada langkah ini, kesalahan yang umumnya terjadi adalah asumsi arah positif gaya dalam momen dan geser yang keliru dan penentuan Panjang bentang pada Freebody kanan. Selain itu, pemilihan diagram yang tepat (kiri atau kanan) untuk memudahkan perumusan gaya - gaya dalam juga dapat membingungkan mahasiswa. Untuk struktur pada soal ini, pemilihan FBKi pada potongan bentang pertama dan $F B K a$ pada potongan bentang kedua akan memudahkan proses perumusan gaya - gaya dalam. Hal ini disebabkan gaya - gaya yang terlibat pada freebody tersebut lebih sederhana.

Penyelesaian - Langkah 3: Penyusunan persamaan gaya-gaya dalam.

Pada FBK $i$ bentang pertama, rentang panjang bentang $x$ adalah dari 0 sampai $6 \mathrm{~m}$. Dengan mengambil $\sum M_{\text {titik potong }}=0$, $\sum M_{\text {titik potong }}=M(x)-A_{1} \cdot x+w_{0} \cdot x \cdot x / 2=0$ $M(x)=A_{y} \cdot x-w_{0} \cdot x^{2} / 2$.

Dengan mengambil $\sum F_{y}=0$,

$\sum F_{y}=-V(x)+A_{y}-w_{0} \cdot x=0$

$V(x)=A_{y}-w_{0} \cdot x$

(Pers.2)
Pada FBKa potongan bentang kedua, rentang panjang $x$ adalah dari $6 \mathrm{~m}$ sampai 8 $\mathrm{m}$. Dengan mengambil $\sum M_{\text {titik potong }}=0$, $\sum M_{\text {titik potong }}=-M(x)-w_{0} \cdot(8-x) \cdot(8-x) / 2=0$ $M(x)=-w_{0} .(8-x)^{2} / 2$.

(Pers.3)

Dengan mengambil $\sum F_{y}=0$,

$\sum F_{y}=V(x)-w_{0} \cdot(8-x)=0$

$V(x)=w_{0} \cdot(8-x)$.

(Pers.4)

Apabila Pers.1 dan 3 digabungkan, maka persamaan momen dapat ditulis sebagai

$M(x)=\left\{\begin{array}{cc}A_{y} x-w_{o} \frac{x^{2}}{2} & 0 \leq x \leq 6 m \\ -w_{o} \frac{(8-x)^{2}}{2} & 6 m<x \leq 8 m\end{array}\right.$

(Pers.5)

dan persamaan geser sebagai

$V(x)=\left\{\begin{array}{cc}A_{y}-w_{o} x & 0 \leq x \leq 6 m \\ w_{o}(8-x) & 6 m<x \leq 8 m\end{array}\right.$

(Pers.6)

Penyelesaian - Langkah 4: Penggambaran bidang gaya - gaya dalam.

Penggambaran bidang gaya - gaya dalam merupakan langkah yang relatif sulit dijelaskan jika mahasiswa tidak memiliki pengetahuan tentang kalkulus yang memadai. Pada umumnya, mahasiswa akan kebingungan untuk memulai penggambaran bidang gaya - gaya dalam ini atau melakukan kesalahan pada kelengkungan kurva; apakah kurva melengkung ke atas atau ke bawah? Sebagian pengajar akan meminta mahasiswa untuk menghitung nilai $M(x)$ dan $V(x)$ untuk beberapa nilai $x$, dan melakukan pengeplotan berdasarkan nilai yang telah dihitung. Beberapa mahasiswa dengan akses terhadap kalkulator grafis akan menggunakan fasilitas tersebut walaupun penggunaan kalkulator jenis ini tidak disarankan untuk mata perkuliahan dasar seperti Statika.

Dari observasi terhadap Pers. 6, maka bidang geser merupakan garis linear karena derajat kepangkatan $x$ adalah 1 . Sedangkan pada Pers. 5, $M(x)$ adalah kurva parabolik (derajat kepangkatan $x$ adalah 2). Nilai momen maksimum dapat dihitung dengan mencari nilai $x$ pada saat geser $=0$ atau dengan mencari turunan $M(x), d M / d x=0$. 
Dari hasil perhitungan ini, nilai $x_{\max }=2.67 \mathrm{~m}$ dan nilai momen maksimum $M_{\max }=35.56$ $\mathrm{kNm}$. Nilai momen minimum, $M_{\text {min }}=-20$ $\mathrm{kNm}$, terjadi pada perletakan $B$ seperti dapat dilihat pada Gambar 4 di bawah ini.

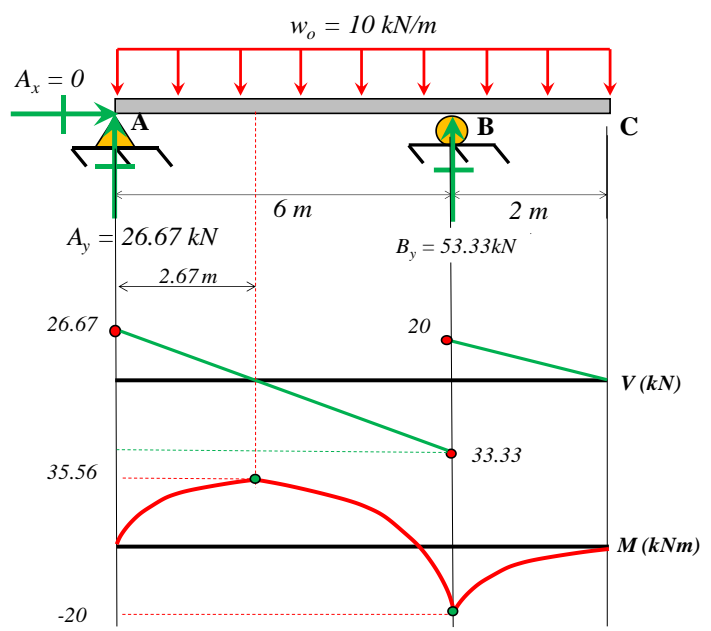

Gambar 4. Bidang geser dan bidang momen contoh soal 1

Seperti dijelaskan sebelumnya, terdapat beberapa kendala utama penerapan metode persamaan yang kerap ditemukan pada mahasiswa dalam pembelajaran Statika: 1) lokasi pemotongan freebody pada tahap pembagian struktur, 2) kesalahan penggambaran dan ketidaktelitian pemilihan freebody diagram yang memudahkan perumusan persamaan, 3) perumusan persamaan gaya dalam, 4) penggambaran bidang geser dan bidang momen. Metode grafis akan mengeliminir kesalahan 1, 2, dan 3 diatas karena metode grafis tidak melalui tahap penyelesaian kedua (pemotongan freebody) dan ketiga (perumusan persamaan).

\section{Metode Grafis}

Metode grafis untuk penggambaran bidang geser dan bidang momen pada umumnya melalui tiga tahapan penyelesaian: 1. Perhitungan reaksi perletakan

2. Penggambaran bidang geser

3. Penggambaran bidang momen

Dapat diamati bahwa metode grafis melompati langkah kedua dan ketiga dari metode persamaan. Hal ini dapat dilakukan karena penggambaran bidang geser dan bidang momen dapat dilakukan secara langsung dengan memahami ke-enam aturan yang akan diturunkan di bawah ini.

Aturan ke-1: $\frac{d V}{d x}=-w$, kemiringan (slope) dari bidang geser pada suatu titik sama dengan negatif dari ordinat dari beban merata pada titik tersebut. Perlu dicatat bahwa ordinat didefinisikan sebagai nilai $y$ dari sebuah fungsi pada koordinat kartesian $x-y$. Selain itu, aturan ini diturunkan dengan asumsi beban merata positif mengarah ke bawah.

Aturan ke-2:

$$
\Delta V=-\int w d x
$$

perbedaan nilai geser di antara dua titik sama dengan negatif dari luasan beban merata di antara kedua titik tersebut.

Kedua aturan ini dapat diturunkan dengan menuliskan $\sum F_{y}=0$ pada potongan freebody yang ditunjukkan pada Gambar 5 $\sum F_{y}=V-(V+d V)-w \cdot d x=0$

$-d V-w d x=0$

$d V=-w d x$

Dengan memindahkan $d x$ pada Pers. 7 dari ruas kanan ke ruas kiri, maka akan didapatkan

$\frac{d V}{d x}=-w$

Apabila kedua ruas pada Pers. 7 diintegralkan, maka akan didapatkan

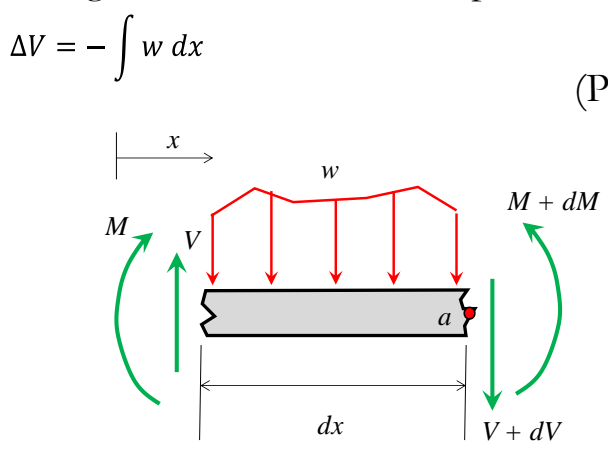

(Pers. 9)

Gambar 5. Freebody diagram untuk penurunan aturan $1-4$

Aturan ke-3: $\frac{d M}{d x}=V$, kemiringan (slope) dari bidang momen pada suatu titik sama dengan ordinat dari bidang geser pada titik tersebut. 
Aturan

ke-4:

$$
\Delta M=\int V d x
$$

perbedaan nilai momen di antara dua titik sama dengan luasan bidang geser di antar kedua titik tersebut.

Aturan ke-3 dan ke-4 juga diturunkan melalui freebody diagram yang sama (Gambar 5), akan tetapi kali ini persamaan $\sum M_{a}=0$ yang harus digunakan.

$\sum M_{a}=(M+d M)-M-V d x+w d x(d x / 2)=$ 0

$\sum M_{a}=d M-V d x+w d x^{2} / 2=0$

$d x$ adalah nilai yang sangat kecil sehingga $d x^{2}$ $\approx 0$.

$\sum M_{a}=d M-V d x=0$

$d M=V d x$

dengan memindahkan $d x$ dari ruas kanan ke ruas kiri pada Pers. 10, maka akan didapatkan $\frac{d M}{d x}=V$

Apabila kedua ruas pada Pers. 10 diintegralkan maka akan didapatkan

$$
\Delta M=\int V d x
$$

Aturan ke-5: $\Delta V=-P$, Nilai bidang geser akan berkurang sebesar nilai beban terpusat pada lokasi dimana gaya terpusat $\boldsymbol{P}$ ke bawah diaplikasikan.

Aturan ini dapat diturunkan dengan meninjau $\sum F_{y}=0$ pada potongan freebody yang ditunjukkan pada Gambar 6.

$$
\begin{aligned}
& \sum F_{y}=V-(V+\Delta V)-P=0 \\
& \Delta V=-P \quad \text { (Pers. 13) }
\end{aligned}
$$

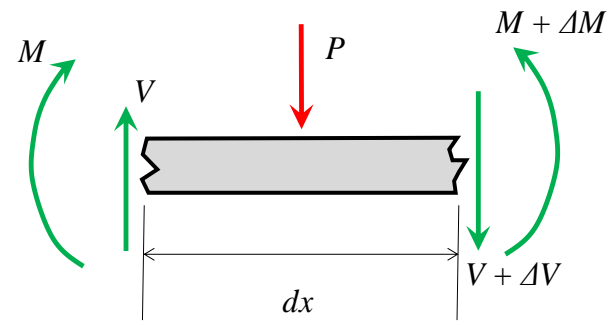

Gambar 6. Freebody diagram untuk penurunan aturan ke-5

$$
\text { Aturan ke-6: } \Delta M=-M_{o}, \quad \text { Nilai }
$$

bidang momen akan berkurang sebesar nilai moment terpusat pada lokasi dimana momen terpusat $\boldsymbol{M}_{o}$ berlawanan arah jarum diaplikasikan.

Aturan ini dapat diturunkan dengan meninjau $\sum M_{a}=0$ pada potongan freebody yang ditunjukkan pada Gambar 7.

$\sum M_{a}=(M+\Delta M)-M+M_{o}-V d x=0$

Nilai $d x$ sangatlah kecil sehingga $V d x \approx 0$, sehingga

$\Delta M=-M_{0}$

(Pers. 14)

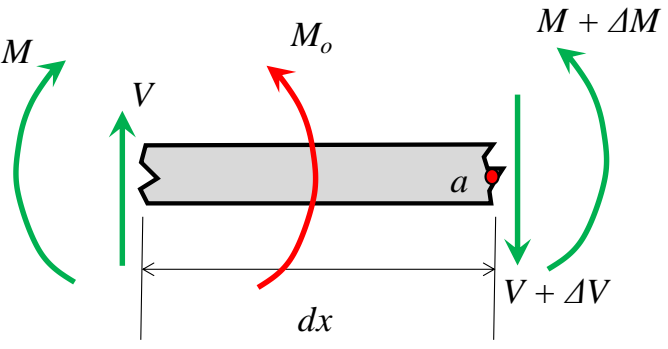

Gambar 7. Freebody diagram untuk penurunan aturan ke-6

Dengan pemahaman ke-enam aturan tersebut maka bidang geser dan bidang momen dapat digambarkan secara langsung tanpa pemotongan freebody dan perumusan persamaan gaya - gaya dalam. Apabila kita perhatikan dengan seksama, aturan ke-1, -2 , dan -5 diperlukan untuk penggambaran bidang geser. Aturan ini sangat bergantung pada gaya yang bekerja pada struktur meliputi beban merata, reaksi perletakan (gaya) dan gaya luar terpusat. Sedangkan aturan ke-3, -4, dan -6 diperlukan untuk penggambaran bidang momen. Ketiga aturan ini bergantung pada bidang geser dan juga momen (reaksi perletakan atau beban luar) yang bekerja pada struktur.

Apabila dicermati lebih dalam, pengaplikasian aturan ke-2 dan ke-4 sangat bergantung pada kemampuan kita menghitung luasan beban merata dan bidang geser. Pada kebanyakan soal - soal di mata kuliah Statika, luasan yang perlu dihitung mencakup persegi panjang, segitiga dan parabolik. Rumus untuk luasan ini pada umumnya dapat ditemukan di tabel pembantu yang banyak terdapat di bagian akhir atau lampiran dari buku acuan Statika. Oleh sebab ini, pengaplikasian metode grafis memiliki keterbatasan dalam artian bahwa selama seseorang bisa menghitung luasan 
untuk bentuk tertentu, maka metode grafis dapat diaplikasikan.

Contoh Soal Penyelesaian dengan Metode Grafis

Untuk meningkatkan pemahaman akan ke-enam aturan yang sudah diturunkan sebelumnya dan pengaplikasian aturan aturan tersebut, dua contoh soal akan dibahas pada bagian ini. Contoh soal 1 sama dengan contoh soal yang dibahas pada metode persamaan. Dengan demikian dapat dibandingkan secara langsung pengaplikasian metode persamaan dan metode grafis. Contoh soal 2 memberikan pengerjaan dengan metode grafis pada soal yang kerap ditemukan di pembelajaran Statika: balok terjepit.

Contoh soal 1

Penyelesaian - Langkah 1: Perbitungan reaksi perletakan

Perhitungan reaksi perletakan sama dengan contoh soal pada metode persamaan, sehingga tidak diulangi lagi. Dari perhitungan, didapatkan reaksi perletakan di tumpuan sendi adalah $26.67 \mathrm{kN}$ (ke atas) dan reaksi perletakan di tumpuan roller adalah $53.33 \mathrm{kN}$ (ke atas).

Penyelesaian - Langkah 2: Penggambaran bidang geser

Penggambaran bidang geser menggunakan aturan ke-1, -2 , dan -5 . Penerapan metode grafis harus selalu dimulai dari kiri balok ke kanan balok. Secara sistematis, penggambaran bidang geser mengikuti tahap berikut ini:

Terdapat reaksi perletakan ke atas di tumpuan sendi sebesar $26.67 \mathrm{kN}$, sehingga nilai geser akan dimulai dengan positif sebesar $26.67 \mathrm{kN}$. Hal ini sesuai dengan aturan ke-5 $(\Delta V=-P$, lihat \#5 pada Gambar 8). Akan tetapi nilai geser bertambah bukannya berkurang karena gaya reaksi perletakan mengarah keatas bukan ke bawah.

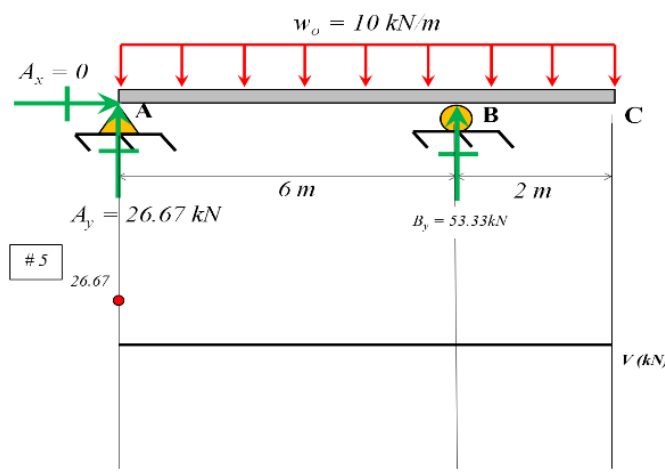

Gambar 8. Penentuan nilai awal bidang geser dengan aturan ke-5

Selanjutnya, perbedaan nilai geser antara titik $A$ dan $B$ dapat dihitung dengan meninjau luasan dibawah beban merata di antara titik $A$ dan $B$ (Aturan ke - 2 $\Delta V=-\int w d x$

). Karena beban meratanya seragam, maka luasan yang dihitung berupa persegi panjang (lihat daerah yang diarsir pada Gambar 9, area $=60 \mathrm{kN}$ ). Berdasarkan aturan ke-2, maka nilai luasan ini merupakan perbedaan (negatif) nilai bidang geser antara titik $A$ dan $B$ (lihat \#2 pada Gambar 9). Sehingga nilai geser pada titik B adalah 26.67 $\mathrm{kN}-60 \mathrm{kN}=-33.33 \mathrm{kN}$.

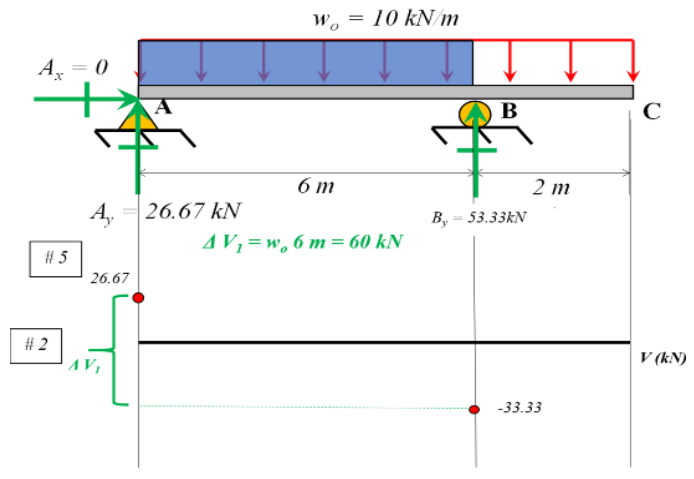

Gambar 9. Penentuan perubahan nilai bidang geser antara titik A dan B dengan aturan ke-2

Berikutnya adalah menentukan jenis garis yang menghubungkan nilai - nilai geser di titik $A$ dan $B$. Berdasarkan aturan ke-1 ( $\frac{d V}{d x}=-w$, lihat \#1 pada Gambar 10), nilai kemiringan bidang geser pada titik $A$ dan $B$ adalah sama $(-10 \mathrm{kN} / \mathrm{m})$ karena ordinat pada beban merata adalah sama. Pada 
kenyataannya, kemiringan setiap titik pada bidang geser antara $A$ dan $B$ adalah sama (karena ordinat beban merata adalah sama), maka dapat dipastikan bahwa garis yang menghubungkan nilai geser di titik A dan B adalah garis lurus (linear). Selain itu, jika diamati lebih jauh, beban merata memiliki fungsi konstan, maka bidang geser harus merupakan fungsi linear jika aturan ke-1 menjadi acuan (turunan fungsi linear adalah konstan).

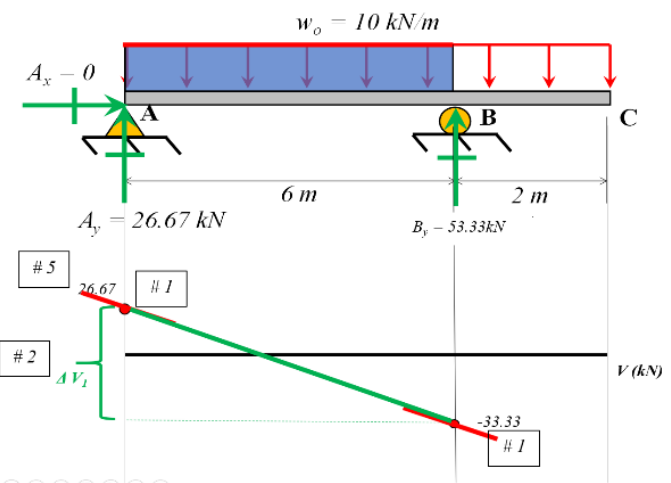

Gambar 10. Penentuan jenis garis yang menghubungi nilai bidang geser di titik A dan B dengan aturan ke-1

Pada sisi kanan titik $B$, nilai bidang geser akan bertambah sebesar nilai reaksi perletakan pada tumpuan roller. Hal ini sesuai dengan aturan ke-5. Dengan demikian nilai geser di sebelah kanan titik $B$ adalah -33.33 $\mathrm{kN}+53.33 \mathrm{kN}=20 \mathrm{kN}$ (lihat Gambar 10).

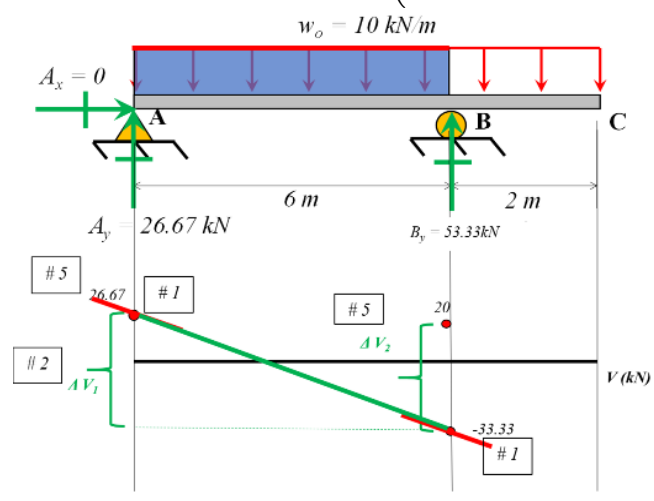

Gambar 11. Penentuan nilai geser di sebelah kanan titik B dengan aturan ke-5

Perbedaan nilai geser antara titik $B$ dan $C$ dapat ditentukan dengan menghitung luas area beban merata antara titik $B$ dan $C$ (lihat luasan beban merata antara titik $B$ dan $C$ yang diarsir pada Gambar 11), dan menurut aturan ke-2, maka nilai bidang geser akan berkurang sebanyak $20 \mathrm{kN}$ menjadi nol di titik $C$.

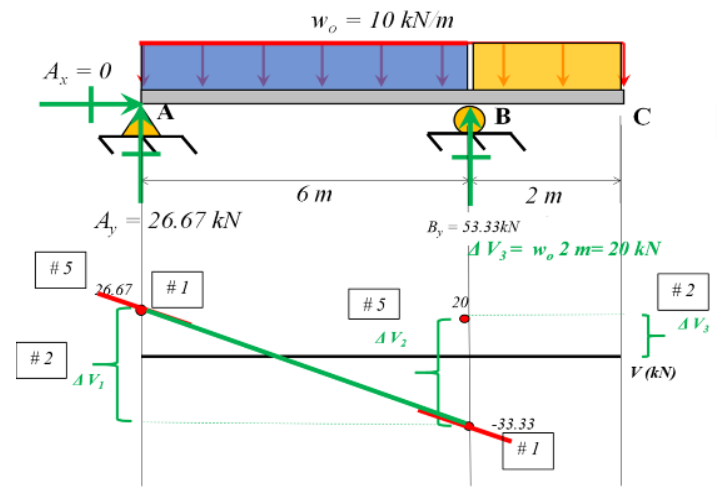

Gambar 12. Penentuan perubahan nilai bidang geser antara titik B dan $\mathrm{C}$ dengan aturan ke-2

Dengan aturan ke-1 dapat dipastikan garis yang menghubungkan nilai geser di titik $B$ dan $C$ adalah garis linear karena nilai beban merata yang seragam (lihat Gambar 12). Hal ini serupa dengan tahap pengerjaan ke-3 yang telah dibahas sebelumnya (lihat Gambar 10).

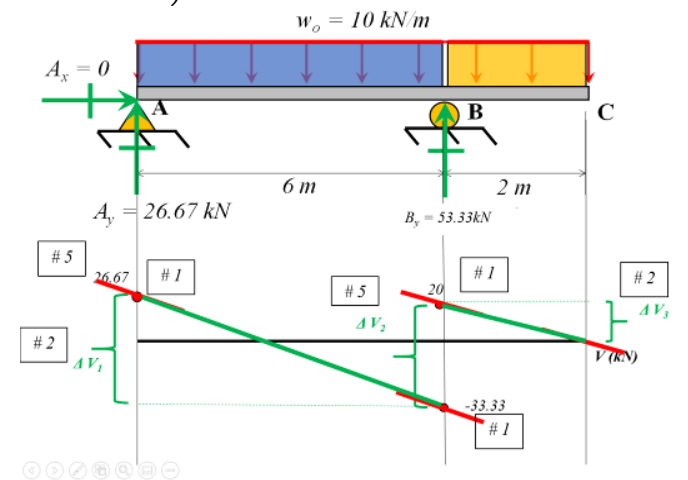

Gambar 13. Penentuan jenis garis yang menghubungi nilai bidang geser di titik B dan C dengan aturan ke-1

Untuk keperluan menghitung nilai momen maksimum, maka perlu dihitung lokasi dimana nilai geser sama dengan nol. Aturan ke-2 dapat diaplikasikan untuk menghitung lokasi tersebut dengan mempertimbangkan bahwa perubahan nilai bidang geser adalah sebesar $26.67 \mathrm{kN}$, maka lokasi dimana nilai bidang geser nol, $x=$ $26.67 \mathrm{kN} / w_{0}=2.67 \mathrm{~m}$ (lihat Gambar 13) 


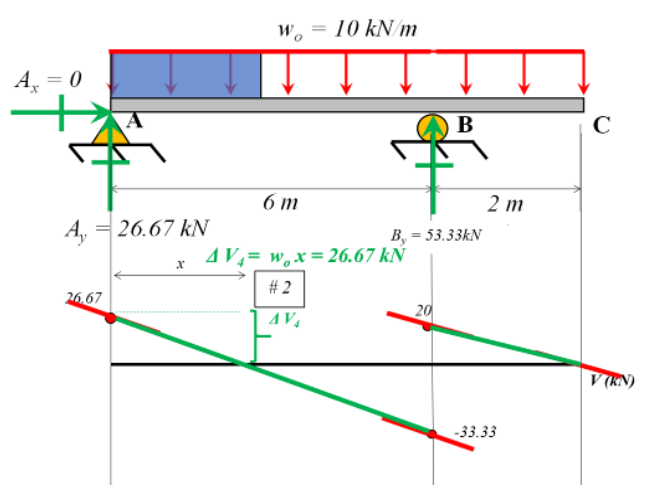

Gambar 14. Penentuan lokasi dimana bidang geser nol

Penyelesaian - Langkah 3: Penggambaran bidang momen

Penggambaran bidang momen menggunakan aturan ke-3, -4, dan -6. Seperti penggambaran bidang geser, penerapan metode grafis harus selalu dimulai dari kiri balok ke kanan balok. Secara sistematis, penggambaran bidang momen mengikuti tahap berikut ini:

Tumpuan $A$ merupakan tumpuan sendi sehingga dapat dipastikan bahwa momen di titik $A$ adalah nol. Selanjutnya perbedaan nilai momen antara: 1) titik $A$ dan titik momen maksimum $(x=2.67 \mathrm{~m}), \Delta M_{1}$; 2) titik momen maksimum $(x=2.67 \mathrm{~m})$ dan titik $\left.B, \Delta M_{2} ; 3\right)$ titik $B$ dan titik $C, \Delta M_{3}$, dapat dihitung berdasarkan aturan ke-4 ( $\Delta M=\int V d x$ ) yakni dengan menghitung luasan segitiga (lihat Gambar 13) pada bidang geser diantara pasangan titik yang dijabarkan diatas. Sehingga $\Delta M_{1}=A_{1}=$ $(0.5)(26.67 \mathrm{kN})(2.67 \mathrm{~m})=35.56 \mathrm{kNm}, \Delta M_{2}$ $=A_{2}=(0.5)(-33.33 \mathrm{kN})(3.33 \mathrm{~m})=-55.56$ $\mathrm{kNm}, \Delta M_{3}=A_{3}=(0.5)(20 \mathrm{kN})(2 \mathrm{~m})=20$ $\mathrm{kNm}$. Dengan demikian, nilai momen di titik momen maksimum adalah $35.56 \mathrm{kNm}$, nilai momen di titik $B$ adalah $-20 \mathrm{kNm}$, dan nilai momen di titik $C$ adalah 0 .

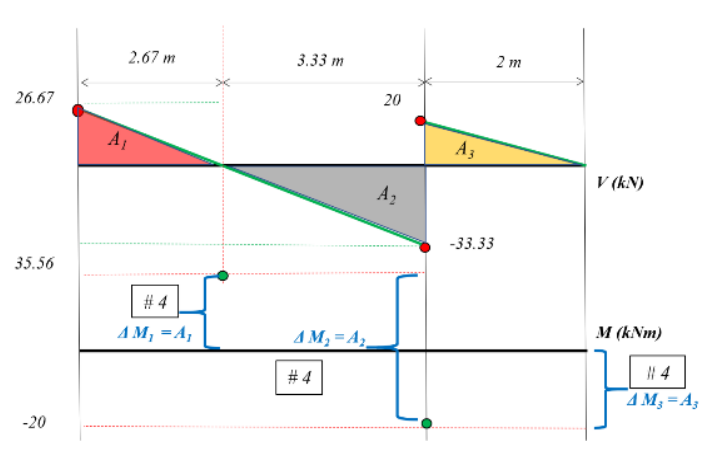

Gambar 15. Penentuan perbedaan nilai momen antara ketiga pasangan titik

Serupa dengan bidang geser, tahap berikutnya adalah menghubungkan nilai bidang momen yang sudah dikalkulasikan dengan garis yang dapat ditentukan dengan aturan ke-3 $\left(\frac{d M}{d x}=V\right)$. Dengan mengamati nilai bidang geser (ordinat) pada titik $A$, titik momen maksimum $(x=2.67 \mathrm{~m})$, titik B dan titik $\mathrm{C}$, dapat dipastikan bahwa kemiringan bidang momen di titik $A$ adalah positif (naik), di titik momen maksimum adalah nol (horizontal), di titik $B$ adalah negatif (turun), dan titik $C$ adalah nol (horizontal) (lihat sketsa garis kemiringan pada Gambar 15).

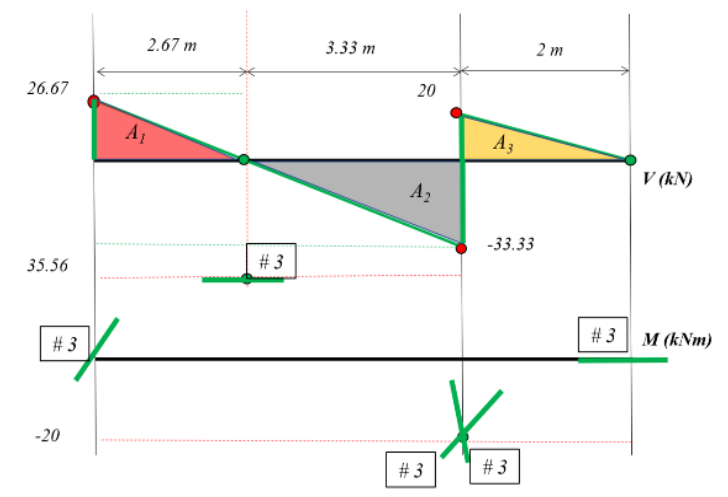

Gambar 16. Penentuan garis kemiringan di titik - titik kritikal pada balok 
Selain itu, dapat pula dipastikan dengan aturan ke-3 bahwa bidang momen akan berbentuk kurva parabolik karena bidang geser adalah garis linear. Dengan demikian, kurva parabolik dapat disketsakan mengikuti garis kemiringan yang sudah ditandai sebelumnya (Lihat Gambar 16).

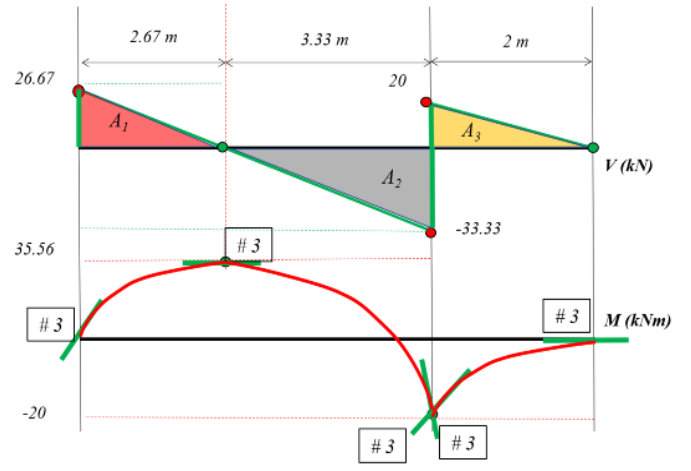

Gambar 17. Penggambaran kurva bidang momen mengikuti garis kemiringan yang sudah ditandai sebelumnya

Contoh soal 1 menunjukkan pengaplikasian aturan ke-1 sampai dengan ke-5. Aturan ke-6, $\Delta M=-M_{o}$, tidak diaplikasikan karena tidak terdapatnya momen terpusat baik dari reaksi perletakan maupun dari beban luar. Contoh soal 2 dibawah ini menunjukkan pengaplikasian aturan ke-6 secara lebih spesifik.

\section{Contoh soal 2}

Sebuah balok kantilever dengan panjang $L$ dijepit di titik $A$ dan terdapat gaya terpusat $P$ pada titik $B$.

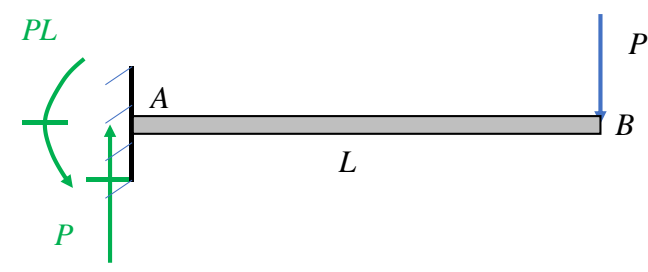

Gambar 18. Contoh soal 2 beserta reaksi perletakan yang sudah dihitung sebelumnya

Penyelesaian - Langkah 1: Perhitungan reaksi perletakan

Reaksi perletakan pada ujung terjepit dapat dihitung dengan menggunakan persamaan kesetimbangan $\sum F_{y}=0$ dan $\sum M_{A}$
$=0$. Hasil perhitungan menunjukkan bahwa reaksi perletakan di titik $A$ adalah gaya vertikal atas sebesar $P$ dan reaksi momen berlawanan arah jarum jam sebesar $P L$.

Penyelesaian - Langkah 2: Penggambaran bidang geser

Serupa dengan contoh soal 1, penggambaran bidang geser menggunakan aturan ke-1, -2, dan -5, dan penerapan aturan tersebut harus selalu dimulai dari kiri balok ke kanan balok. Penggambaran diagram geser untuk contoh soal ini dimulai terlebih dahulu dengan aturan ke-5 $\left(\Delta P=-P_{0}\right)$ karena terdapat gaya reaksi $P$ yang mengarah ke atas. Dengan demikian, nilai bidang geser akan dimulai dengan $+P$ di titik $A$. Setelah meninjau bahwa tidak terdapatnya beban merata pada bentang $A B(w=0)$, maka menurut aturan ke-2 $(d V / d x=-w)$ bidang geser akan berupa fungsi konstan (turunan dari fungsi konstan adalah nol). Bidang geser untuk struktur ini ditunjukkan pada Gambar 18.

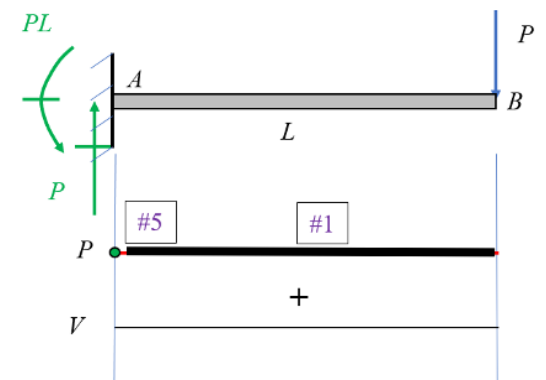

Gambar 19. Bidang geser contoh soal 2 berupa fungsi konstan

\section{Penyelesaian - Langkah 3: Penggambaran bidang momen}

Penggambaran bidang momen menggunakan aturan ke-3, -4, dan -6. Seperti penggambaran bidang geser, penerapan metode grafis harus selalu dimulai dari kiri balok ke kanan balok. Penggambaran bidang momen untuk struktur ini dimulai dengan menerapkan aturan ke-6 $\left(\Delta M=-M_{0}\right)$ karena terdapat reaksi momen pada titik $A$. Oleh karena reaksi momen memiliki arah berlawanan jarum jam seperti yang dirumuskan pada aturan ke-6, maka nilai bidang momen pada titik $A$ adalah PL.Setelah itu perbedaan bidang momen 
antara titik $A$ dan $B$ dapat dihitung dengan meninjau luasan pada bidang geser antara titik $A$ dan $B$ sesuai dengan aturan ke-4. Nilai luasan ini adalah $+P L$ karena area berbentuk persegi panjang. Dengan demikian nilai bidang momen pada titik $B$ adalah 0 . Garis linear diperlukan untuk menghubungkan kedua titik ini karena berdasarkan aturan ke$3(d M / d x=V)$ turunan garis linear merupakan fungsi konstan yang merupakan fungsi pada bidang geser. Bidang momen dari balok kantilever digambarkan pada Gambar 19.

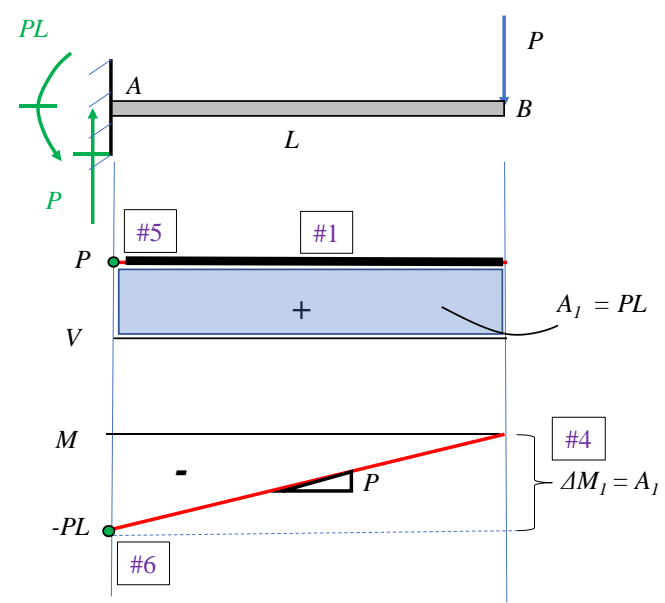

Gambar 20. Penggambaran bidang momen contoh soal 2

\section{Metode Penelitian}

Untuk menguji keandalan dari metode grafis ini, penelitian dilakukan terhadap mahasiswa yang mengambil mata kuliah Statika I di Universitas Tanjungpura pada tiga tahun ajaran yang berbeda. Metode persamaan diperkenalkan kepada mahasiswa pada tahun ajaran I, dan metode grafis diperkenalkan pada mahasiswa di tahun ajaran II dan III. Topik penggambaran gaya - gaya dalam, termasuk penggambaran bidang geser dan bidang momen diuji pada Ujian Akhir Semester (UAS) pada ketiga tahun ajaran tersebut.

Contoh soal UAS pada tahun I, II, dan III ditunjukkan pada Gambar 20. Penulis berpendapat bahwa tingkat kesulitan dari UAS yang diberikan pada ketiga tahun ajaran tersebut relatif sama. Soal - soal tersebut secara umum mencakup struktur balok dengan pembebanan merata dan terpusat. Pada soal tahun I dan III, struktur balok yang ditinjau adalah struktur balok Gerber. Pada soal tahun II dan III terdapat beban momen luar. Secara beban pengerjaan, soal UAS tahun II terlihat lebih mudah karena reaksi perletakan pada struktur tersebut sudah diberikan. Akan tetapi, perlu dicatat bahwa terdapat soal lain di UAS tahun II yang khusus menanyakan mahasiswa untuk menghitung reaksi perletakan. Secara umum, mahasiswa pada ketiga tahun tersebut diharuskan untuk menggambarkan bidang geser dan bidang momen. Walaupun penulis berpendapat bahwa soal - soal ujian tersebut memiliki taraf kesulitan yang relatif sama, untuk keperluan penilitian pengajaran di bidang teknik kedepannya, diperlukan sekumpulan set soal (concept inventory test) yang dapat dijadikan acuan ukur yang lebih objektif.

UAS pada tahun I dan III disusun dan dikoreksi oleh penulis pertama. Sedangkan UAS pada tahun II disusun oleh penulis pertama dan kedua dan dikoreksi oleh penulis kedua. Adapun untuk pengajarannya, tahun I dan III difasilitasi oleh penulis pertama, tahun II difasilitasi oleh penulis kedua (instruktur utama) dan pertama. Penulis pertama memiliki pengalaman mengajar lebih dari 30 tahun untuk mata kuliah Statika di Universitas Tanjungpura dan penulis kedua memiliki pengalaman mengajar lebih dari 10 tahun untuk mata kuliah Statika baik di Indonesia maupun di Amerika Serikat. Oleh sebab itu dapat diasumsikan bahwa pengajar sudah memiliki pengetahuan dan pengalaman yang cukup dalam pengajaran bidang Statika.

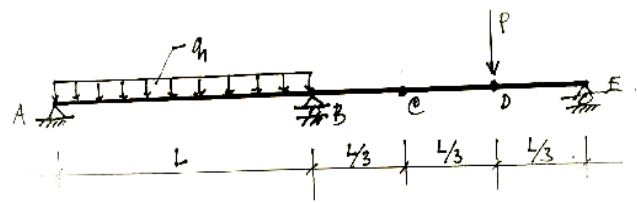

a) Tahun I - perletakan sendi di A, perletakaan roller di B dan E, sambungan sendi di C. 


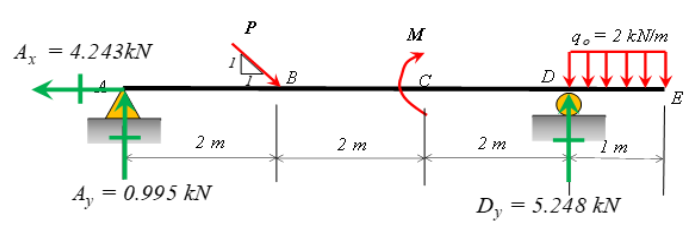

b) Tahun II - perletakan sendi di A dan roller di D - reaksi perletakan diberikan dalam soal

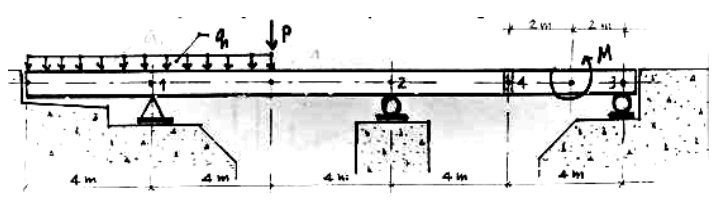

c) Tahun III - perletakan sendi di 1 , perletakan roller di 2 dan 3, sambungan sendi di 4.

\section{Gambar 21. Contoh soal UAS di ketiga tahun ajaran.}

Waktu pengerjaan UAS pada ketiga tahun ajaran tersebut adalah sama dan peralatan tulis dan menghitung (kalkulator biasa tanpa kemampuan grafis) yang diperkenankan juga sama. Nilai UAS pada ketiga tahun ajaran tersebut akan diolah secara Statistik untuk menguji hipotesis bahwa terdapat perbedaan yang signifikan antara nilai ujian pada tahun ajaran I dan II dan pada tahun ajaran I dan III. Kedua hipotesis tersebut membandingkan nilai UAS mahasiswa yang dalam perkuliahan diajarkan metode persamaan dan metode grafis.

\section{Hasil Penelitian dan Pembahasan}

\section{Data Statistik Umum}

Tabel 1 menunjukkan data statistik nilai UAS pada ketiga tahun ajaran dengan nilai maksimum yang mungkin dicapai adalah 100 poin. Dari UAS, dapat diamati bahwa mahasiswa yang terekspos dengan metode grafis memiliki nilai rata - rata yang lebih tinggi dibandingkan dengan mahasiswa yang belajar dengan menggunakan metode persamaan. Nilai rata - rata pada tahun II adalah yang tertinggi dan lebih tinggi dari nilai rata - rata tahun III walaupun metode grafis diperkenalkan di kedua tahun ajaran.
Hal ini mungkin disebabkan oleh beban pengerjaan yang lebih rendah yakni tidak perlu menghitung reaksi perletakan untuk soal bidang geser dan bidang momen. Pengamatan terhadap nilai rata - rata ini sebanding dengan pengamatan pada median nilai UAS di ketiga tahun ajaran tersebut, yakni tahun II memiliki nilai median tertinggi disusul dengan tahun III dan tahun I. Nilai UAS tahun ajaran I dan III memiliki koefisien variasi diatas 0.5 dan jauh lebih besar dari koefisien variasi pada tahun ajaran II. Hal ini mungkin disebabkan karena UAS pada tahun ajaran II dikoreksi oleh penulis kedua dan UAS tahun I dan III dikoreksi oleh penulis pertama sehingga terdapat perbedaan standar penilaian. Terlepas dari data ujian tahun II, metode grafis masih menunjukkan peningkatan yang signifikan yakni sebesar 155\% jika rata - rata UAS tahun I dan III dibandingkan secara langsung.

Tabel 1. Perbandingan nilai UAS tahun ajaran I, II, dan III

\begin{tabular}{llll}
\hline Tahun & I & II & III \\
\hline Rata - rata & 22.36 & 70.04 & 57.24 \\
Median & 20 & 72 & 64 \\
$\begin{array}{l}\text { Koef. Var } \\
\begin{array}{l}\text { Jumlah } \\
\text { mahasiswa }\end{array}\end{array}$ & 0.66 & 0.21 & 0.57 \\
\hline
\end{tabular}

Pengujian Hipotesis

Beberapa penelitian sebelumnya (Hardiyanti et al., 2012, Utami et al., 2016) menggunakan uji-t untuk menguji hipotesis akan signifkansi dari suatu variabel terhadap suatu sistem. Untuk meneliti signifikansi dari penggunaan metode grafis terhadap pencapaian nilai UAS pada studi ini, pengujian hipotesis dilakukan terhadap nilai UAS pada ketiga tahun ajaran dengan menggunakan metode nonparametrik MannWhitney. Metode nonparametrik dipilih karena data nilai UAS pada ketiga tahun ajaran tidak mengikuti distribusi normal sehingga pengujian hipotesis untuk signifikansi metode grafis tidak bisa 
dilakukan dengan metode parametrik seperti uji-t (Riadi, 2016, Suharyadi, 2016). Pengujian normalisasi data dilakukan dengan metode Liliefors, dan untuk ketiga tahun ajaran $L_{\text {bitung }}>L_{\text {tabel }}$ Sehingga disimpulkan bahwa nilai UAS pada ketiga tahun ujian tidak memiliki distribusi normal.

Tabel 2. Perbandingan L pada uji normalisasi Liliefors

\begin{tabular}{lccc}
\hline & Tahun I & Tahun II & Tahun III \\
\hline$L_{\text {bitung }}$ & 0.293 & 0.083 & 0.115 \\
$L_{\text {tabel }}$ & 0.146 & 0.037 & 0.041 \\
\hline
\end{tabular}

Terdapat dua hipotesis yang akan diuji secara terpisah dengan metode Mann-Whitney dengan mempertimbangkan 2 tails dan level signifkansi, $\alpha=0.05: 1) \mathrm{H}_{\mathrm{o} 1}$ : Tidak ada perbedaan yang signifikan pada hasil UAS tahun ajaran I dan II, 2) $\mathrm{H}_{\mathrm{o} 2}$ : Tidak ada perbedaan yang signifikan pada hasil UAS tahun ajaran I dan III.

Tabel 3. Hasil pengujian hipotesis

\begin{tabular}{lllll}
\hline & $\mathbf{z}_{\text {hitung }}$ & $\mathbf{z}_{\text {crit }}$ & $\mathbf{r}$ & Hasil \\
\hline $\begin{array}{l}\text { Uji } \\
\text { pertama }\end{array}$ & -6.18 & -1.96 & 0.79 & $Z_{\text {hitung }}<Z_{\text {crit }}$ \\
\hline $\begin{array}{l}\text { Uji } \\
\text { kedua }\end{array}$ & -3.74 & -1.96 & 0.49 & $Z_{\text {hitung }}<Z_{\text {crit }}$ \\
\hline
\end{tabular}

Tabel 3 menunjukkan hasil penguiian hipotesis dengan metode Mann-Whitney. Nilai zhitung dihitung dengan prosedur MannWhitney, dan hasil ini akan dibandingkan dengan zarit yang dihitung berdasarkan level signifikansi $\alpha$. Hasil perbandingan nilai zbitung dan zorit membantah kedua null-hipotesis yang diuji. Sehingga dapat disimpulkan: 1) Terdapat perbedaan yang signifikan pada UAS tahun I dan II pada nilai zhitung $<$ zarit dengan size effect, $r$ besar $(r>0.5), 2)$ Terdapat perbedaan yang signifkan pada UAS tahun I dan II pada nilai ₹zitung $<$ qurit dengan size effect, $r$ moderat $(0.3<r<0.5)$. Melihat dari nilai rata - rata tahun ajaran II dan III yang lebih besar dari tahun ajaran I. Maka disimpulkan bahwa perbedaan signifikan ini merupakan hal yang positif bagi penggunaan metode grafis. Hal ini juga dapat dikonfirmasi lewat hasil perhitungan ₹ pada prosedur Mann-
Whitney yang bernilai negatif disaat tahun ajaran I diidentifikasikan sebagai data ke-1 dan tahun ajaran II dan III sebagai data ke2.

Selain hasil ujian, penulis juga mengadakan survei sukarela anonim dimana mahasiswa diminta untuk memberikan penilaian dari skala 1-5 untuk pertanyaan "Seberapa terbantunya Anda dengan metode grafis dalam penyelesaian soal yang meliputi gaya - gaya dalam?". Skala 1 memiliki makna sangat tidak membantu, dan skala 5 memiliki makna sangat membantu. Dari 22 mahasiswa yang memberikan respon pada tahun ajaran II, 14 diantaranya bersedia hasil survei digunakan untuk keperluan penelitian. Nilai rata - rata dari ke-14 data tersebut adalah 4.0 yang memiliki makna bahwa, secara umum, metode grafis membantu mahasiswa dalam tahun ajaran II dalam pemahaman topik bidang geser dan bidang momen.

\section{Simpulan dan Saran}

Metode grafis memiliki banyak keunggulan dibandingkan dengan metode persamaan yang umumnya diajarkan pada mata kuliah Statika di Indonesia. Keunggulan utama dari metode ini adalah sifatnya yang lebih efisien dan meminimalisir terjadinya kesalahan. Akan tetapi, metode grafis juga memiliki keterbatasan yakni berkaitan dengan kemampuan mahasiswa untuk menghitung luasan bentuk tertentu. Hal ini dapat diminimalisir karena pada umumnya mahasiswa cukup menghitung luasan persegi panjang atau segitiga yang tentunya sudah fasih bagi mereka. Untuk bentuk - bentuk yang lebih rumit, beberapa buku acuan statika memberikan panduan pada bagian lampiran yang dapat juga digunakan oleh mahasiswa.

Menimbang keuntungan dari metode grafis ini, penulis menyarankan metode grafis diperkenalkan dalam pengajaran bidang geser dan bidang momen pada mata kuliah Statika baik di tingkat universitas maupun di tingkat pendidikan vokasi. Pengenalan ini tidak memiliki artian bahwa metode persamaan harus dihilangkan

$$
\text { Metode Grafis Untuk... - } 81
$$$$
\text { Lingga }
$$ 
seutuhnya. Penulis berpendapat walaupun metode persamaan terbilang kompleks, beberapa mahasiswa terutama mereka dengan kemampuan kalkulus yang lebih baik dapat menggunakannya untuk kasus yang lebih umum dimana perhitungan luasan pada metode grafis menjadi rumit. Pertimbangan lain pengajaran metode grafis dalam mata kuliah Statika adalah sifatnya yang intuitif dan efisien. Sehingga metode ini akan efektif bagi mahasiswa dalam dunia kerja terutama untuk meningkatkan sense of engineering dalam menanggapi hasil - hasil gaya dalam yang dihasilkan oleh software analisis struktur.

\section{Daftar Pustaka}

Goodno, B., \& Gere, J. (2019). Statics and Mechanics of Materials. Cengage

Hardiyanti, S., Iriani, T., \& Nasution, N. (2012). Perbedaan Hasil Belajar Statika Antara Metode Ceramah Dengan Method Problem Posing Pada Siswa
Kelas XII Teknik Konstruksi Kayu SMK Negeri 1 Jakarta. Jurnal Pendidikan Teknik Sipil, 1(2), 141-154.

Riadi, E. (2016). Statistika Penelitian. Andi Offset

Steif, P. S., \& Dantzler, J. (2005). A Statics Concept Inventory: Development and Pyschometric Analysis. Journal of Engineering Education, 33, 363 - 371.

Suharyadi, Purwanto S.K. (2016). Statistika untuk Ekonomi dan Kenangan Modern. Salemba Empat.

Utami, S., Neolaka, A., \& Suyadi, D. (2016). Perbedaan Hasil Belajar Statika Model Pembelajaran Cooperative Learning Tipe Think Pair Share dengan Konvensional Plus (Studi Eksperimen Siswa kelas X Kompetensi Keahlian Teknik Gambar Bangunan SMK Negeri 56 Jakarta). Jurnal Pendidikan Teknik Sipil, 5(2), 1-8. 